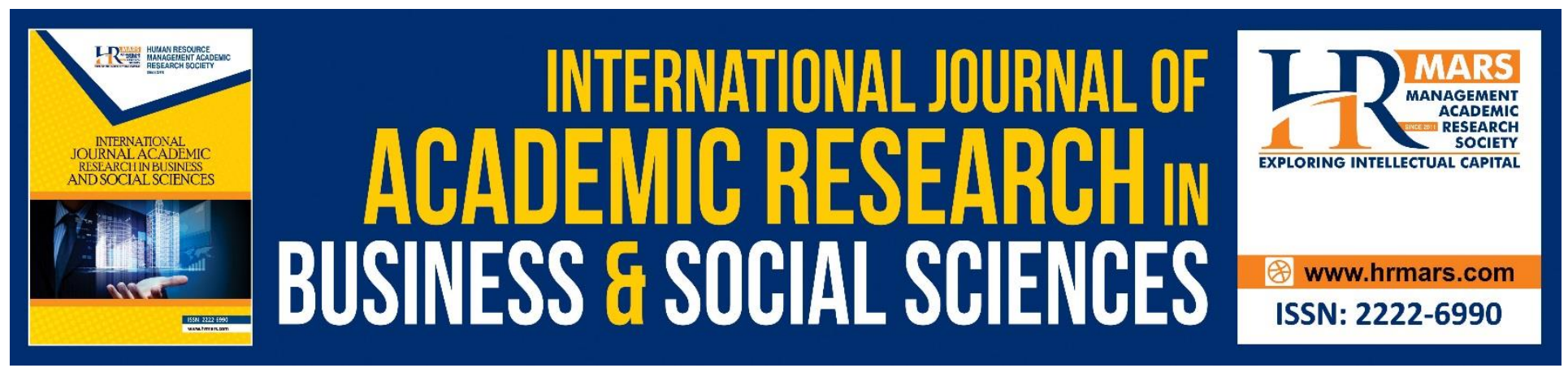

\title{
A Conceptual Framework of Digital Storytelling (Dst) Elements on Information Visualisation (Infovis) Types in Museum Exhibition for User Experience (Ux) Enhancement
}

Hafizah Rosli, Norfadilah Kamaruddin

To Link this Article: http://dx.doi.org/10.6007/IJARBSS/v10-i9/7721

DOI:10.6007/IJARBSS/v10-i9/7721

Received: 13 June 2020, Revised: 16 July 2020, Accepted: 19 August 2020

Published Online: 17 September 2020

In-Text Citation: (Rosli, \& Kamaruddin, 2020)

To Cite this Article: Rosli, H., \& Kamaruddin, N. (2020). A Conceptual Framework of Digital Storytelling (Dst) Elements on Information Visualisation (Infovis) Types in Museum Exhibition for User Experience (Ux) Enhancement. International Journal of Academic Research in Business and Social Sciences. 10(9). 185-198.

Copyright: (C) 2020 The Author(s)

Published by Human Resource Management Academic Research Society (www.hrmars.com)

This article is published under the Creative Commons Attribution (CC BY 4.0) license. Anyone may reproduce, distribute, translate and create derivative works of this article (for both commercial and non-commercial purposes), subject to full attribution to the original publication and authors. The full terms of this license may be seen at: $\underline{\text { http://creativecommons.org/licences/by/4.0/legalcode }}$

Vol. 10, No. 9, 2020, Pg. 185 - 198

http://hrmars.com/index.php/pages/detail/IJARBSS

JOURNAL HOMEPAGE

Full Terms \& Conditions of access and use can be found at

http://hrmars.com/index.php/pages/detail/publication-ethics 


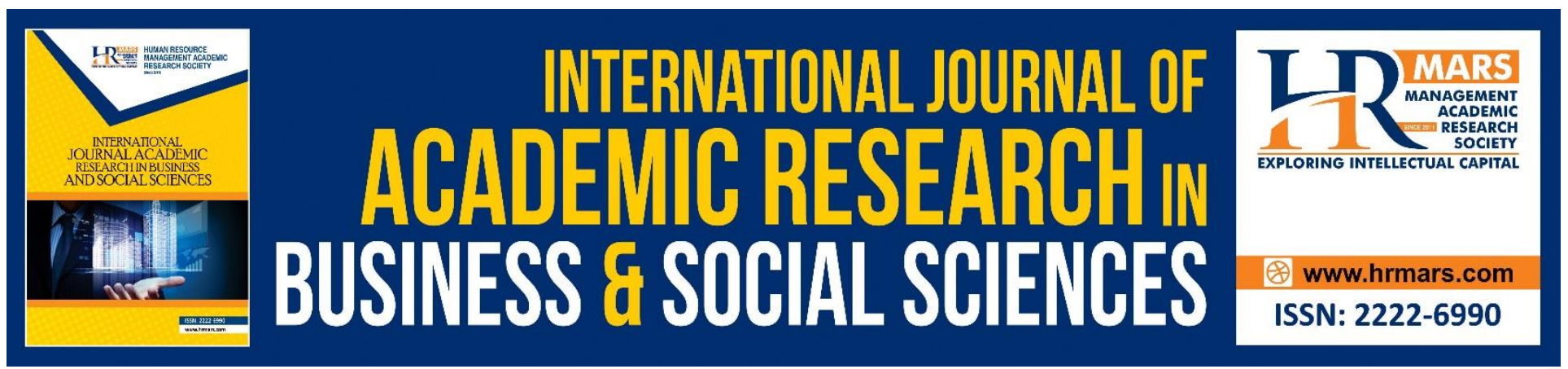

\title{
A Conceptual Framework of Digital Storytelling (Dst) Elements on Information Visualisation (Infovis) Types in Museum Exhibition for User Experience (Ux) Enhancement
}

\author{
Hafizah Rosli \\ Faculty of Art and Design, Universiti Teknologi MARA, UiTM Shah Alam, 40450 Shah Alam, Selangor, \\ Email: hafizahrosli@uitm.edu.my \\ Norfadilah Kamaruddin \\ Faculty of Art and Design, Universiti Teknologi MARA, UiTM Puncak Alam Campus, 42300 Puncak \\ Alam, Selangor, Malaysia \\ Email: norfadilah@uitm.edu.my
}

\begin{abstract}
The coming of age in digital technology brought multifarious user experience (UX) in its various uses. Development in cutting-edge technologies has brought changes in museum exhibitions to improve visitors' engagement and enhance their appreciation of the exhibits but most importantly the heritage which is being showcased. Technology integration in museum exhibits would enables curators to create interactive and multi-sensory UX for museum visitors. Hence, the current paper presents the conceptual framework of the digital storytelling (DST) elements on information visualisation (InfoVis) museum exhibition for user experience (UX). To date, there is an absence of explicit reports on DST elements used in museum exhibition content in designing the exhibition product narration but further exploration is recommended. Utilising the systematic literature review (SLR) method on this study through literature review of DST elements and InfoVis types addressing museum exhibition for user experience (UX), the review is expanded on the technique of enhancement in museum exhibition. However, it is important to identify what are the DST elements and InfoVis types used in contemporary museum exhibitions especially in the National Museum Department (Jabatan Muzium Negara) (JMN) within the Klang Valley area. Additionally, users' reactions towards museum exhibition and curator feedback on what are the best DST elements and InfoVis types will be applied for future museum exhibition in Malaysia for improvised user experience (UX).
\end{abstract}

Keywords: Museum, Digital Storytelling, Information Visualisation, User Experiences 
INTERNATIONAL JOURNAL OF ACADEMIC RESEARCH IN BUSINESS AND SOCIAL SCIENCES Vol. 10, No. 9, 2020, E-ISSN: 2222-6990 @ 2020 HRMARS

\section{Introduction}

Stories have been told and passed down in a variety of ways and had undergone major transformation. With the emergence of new and cutting-edge technologies, and new development in multimedia with its rich features that include audio, video, animation, and graphics, storytelling has evolved from its traditional roots at the expense of its real communication and education values. The popular term for the use of multimedia in storytelling is digital storytelling (DST), a term that was coined due to the effects of fast-paced technology evolution has in the presentations of a narrative (Banaszewski, 2005; Lambert, 2006; Ohler, 2008; Robin, 2008). The roots of storytelling goes as far back as drawing on walls to other forms in written or oral presentations. However, as centuries passed and with technological evolution, the integration of multimedia in storytelling put its presentation in new and different perspectives. The application of DST combines the art of traditional storytelling with other multimedia elements which include images, graphics, music, and audio-visuals in efforts to craft a personally voiced narrative (Porter, 2004; Robin, 2008). The transition to DST from its conventional digital form was introduced by the late Atchleys (Lambert, 2006). The digital stories created by the digital storytellers would become their personal mementos to be shared with others. Hence, the elements included in DST are fundamental to guide aspiring digital storytellers in designing and developing effectual DST. Though the design and development of the DST is dynamic and not prescribed (Lambert, 2006), the elements identified could assist in transforming a typical digital story into a paragon of narrative. The work by Schafer (2008) is instrumental in introducing a reference model of DST that includes dimensions or elements of DST but they cannot be considered as an efficacious core because the elements introduced are inclined towards one form of the DST which is the interactive form. Therefore, the model and elements provided by Shafer (2008) do not represent the other significant half of the DST which is the non-interactive form. Hence, this needs to be thoroughly looked into in attempts to design and develop DST for museum exhibits.

Museum curators have now shift from using traditional exhibition designs to integrating digital technology for museum exhibitions that is not only existential but also tangible for user experience (UX). Museum visitors are those from various walks of life with different knowledge and cultural experiences. At times, the museum is regarded as a space for travel location and entertainment or it is a place fit for those who seek for educational experiences (Hornecker \& Stifter, 2006). Therefore, visitors' expectations in experiencing the museum exhibits would affect the curation of artefacts especially when museum visitors hold the perception that they can have a completed excursion during a day's visit. Significantly, it has been cautioned that an exhibit which cannot create an incentive within ten seconds is usually abandoned (Hornecker \& Stifter, 2006). This leads to the concern raised by (Nee, et al., 2014) that most museum exhibits are kept behind glazed cabinets which may be considered as a barrier to museum experience. Consequently, these contextual characteristics impose some challenges on the creation of information visualisations for museums.

Museums in Malaysia have three types of exhibitions; namely, permanent exhibition, temporary exhibition, special exhibition, and mobile exhibition that employ information visualization (InfoVis) by manipulating presentation characteristics of motion, 2D, 3D, colours, and shape with label panels to communicate with the visitors (Kamaruddin, 2019). The term of information visualisation (InfoVis) can be taken as an umbrella term to describe all kinds of visualisation representations (Weber \& Tille, 2011). Data visualisations can generally be used to facilitate the exploration and analysis of data to 
INTERNATIONAL JOURNAL OF ACADEMIC RESEARCH IN BUSINESS AND SOCIAL SCIENCES Vol. 10, No. 9, 2020, E-ISSN: 2222-6990 @ 2020 HRMARS

arrive at discoveries or to communicate existing insights, knowledge, or arguments (Munzner, 2014). Moreover, visualisations are eminent in storytelling (Segel \& Heer, 2010; Kosara \& Mackinlay, 2013; Lee et al., 2015) and significantly, visualisation of cultural data can also be used for presentation and display which may be static and interactive. This form of 'storytelling' can be used to communicate and argue a point of view, and curate paths and sequences that can be employed to present a narrative of a collection (Davis et al., 2016)

The integrated features of digital storytelling (DST) elements in museum information visualisation (InfoVis) have prompted many countries to continuously improve and enhance museum visitors' experiences. Curators have now put the advantage of digital technology to provide visitors with more tangible experimental ambiance through an engaging exhibition that foster user experience. Allen et. al. (2013) suggested that curators could improve museum experience by integrating interactive and multi-sensory technology but most importantly, to be able put more 'life' for the exhibits by manipulating cutting-edge UX paraphernalia. Not only that, the use of DST could kindle the historical opulence and may include some elements of gamification and movie magic. Consequently, the application of DST could help set deeper emotional connections than just intellectual understanding (Bedford, 2001). It would be essential to consider the ability of DST to incorporate many elements of traditional storytelling and explore different learning styles when designing and developing to enhance museum visitors' experiences (Springer, Brazas, and Kajder, 2004).

In Malaysia, the cultural sector revenue saw an economic impact of RM585.4 million, comprising the clusters of arts and crafts and visual arts with RM547.9 million, performing arts with RM28.7 million, cultural heritage with RM4.1 million, and others for RM4.7 million (Berita Harian, 2020). Meanwhile, for museums which fall into the category of cultural heritage, is considered as the main contributor to cultural sector revenue and managed by the National Museum Department (JMN) with a total of 22 museums in the whole region of Malaysia (Salleh, 2013). The Ministry of Tourism, Art, and Culture of Malaysia is targeting 3.2 million visitors to the museums across the country (Hamat, 2020) in attempts to increase annual revenue. Regrettably, the 2018 Annual Report by JMN revealed a declining number of visitors by four percent and cultural heritage revenues of about twelve percent from 2014 to 2016 through its triennial documentation. The decline may be due to various factors which include ineffectual implementation and design failure of the InfoVis in museums that subsequently failed to capture museum visitors' attention and interest to communicate or churn information form the exhibits (Shah et. al., 2019). This is supported recently by (Rosli \& Kamaruddin, 2020) and emphasised the need for accentuated curation of heritage and archaeological artefacts for improved visitors' experience.

\section{Literature Review}

\section{Functional Specifications for Museum Exhibition}

\section{Digital Storytelling in Museum}

Digital storytelling (DST) is a combination of the art of storytelling and digital media such as audio, video, and graphic to convey a story. The stories can be presented with the combination of videos or narrated through a sequence of plots digitally. This is an art-based research method has the potential to meaningfully capture participants' lived experiences and findings may be shared in a highly engaging manner (Vecchi, et.al., 2016). The method involves the creation of three to five minutes 
INTERNATIONAL JOURNAL OF ACADEMIC RESEARCH IN BUSINESS AND SOCIAL SCIENCES Vol. 10, No. 9, 2020, E-ISSN: 2222-6990 @ 2020 HRMARS

visual narratives that synthesize images, video, audio and text to create compelling accounts of experiences (Gubrium, 2009). This innovative research method holds potential to elucidate complex stories in an entrancing and accessible manner and increase participants' and users' engagement with the research process. Interestingly, art-based knowledge translation approaches such as DST would be able to be utilised to convey nuanced meanings for diverse audiences. Various forms could be employed in developing DST that include short videos to digital storytelling, web-based storytelling, and multiplayer gamification role-play while gradually penetrating various disciplines (Lambert, 2006).

Through the emergence of new technology and the development of multimedia with its rich media elements including audio, video, animation and graphics, storytelling methods have evolved from its traditional roots but still with holding its genuine objective of dispersing knowledge (Tenh et. al., 2012). Nonetheless, the key elements employed in DST may be limited to only two categories which is the inclusion of interactive and non-interactive elements (Tenh et. al., 2012). Harun and Shiratuddin (2009) had established a set of DST elements in order to construct a good digital story. Based from the literature review conducted, most of the DST researchers would refer to Lambert's set of elements for digital story construction this is because Lambert with his set of elements because they are easy to understand and suitable to implement in DST construction (Harun and Shiratuddin, 2009).

\section{Non-interactive DST}

The non-interactive DST is generally a linear story presentation. It is mainly a personal story told through computer technology and is usually a short multimedia presentation of about two to ten minutes with a combination of different digital media such as photo, video, animation, sound, music, text, and narrative voice.

\section{Interactive DST}

Interactive digital storytelling (DST) is an application that requires and enables the audiences or users of the application to interact throughout the story progression. More interestingly, sometimes it could even extend to getting the involvement of the audiences or users to influence the flow of the story. 
INTERNATIONAL JOURNAL OF ACADEMIC RESEARCH IN BUSINESS AND SOCIAL SCIENCES Vol. 10, No. 9, 2020, E-ISSN: 2222-6990 @ 2020 HRMARS

\begin{tabular}{|c|c|}
\hline $\begin{array}{c}\text { NON - INTERACTIVE } \\
\text { DST ELEMENTS }\end{array}$ & $\begin{array}{c}\text { INTERACTIVE } \\
\text { DST ELEMENTS }\end{array}$ \\
\hline Perspective & Perspective \\
\hline Intention & Intention \\
\hline Personal & Personal \\
\hline Dramatical Question & Dramatical Question \\
\hline Engagement & Engagement \\
\hline Articulation & Articulation \\
\hline Soundtrack & Soundtrack \\
\hline Minimal & Tempo \\
\hline Tempo & Story Map \\
\hline Story Map & Expression \\
\hline Expression & Significant Content \\
\hline & Collaboration \\
\hline User Contribution \\
\hline
\end{tabular}

Table 1: Core elements and categories of digital storytelling (Tenh et. al., 2012).

The use of digital storytelling has only recently emerged as an effective way to engage visitors in the field of cultural heritage and comes with two key interpretations. First, it is conceived as a better channel type of user-generated content to tell a story of museum artefacts or displays. Second, it provides a space for curators and experts involved to demonstrate their abilities at conveying stories on cultural subjects using Web 2.0. A study from European commission toward their Cultural Heritage Experiences through Socio-personal interactions and Storytelling (CHESS) project conducted at Acropolis Museum in Greece, and the Cite de I 'Espace in France, is performed for visitors to explore museum collections by series of defines stories. The CHESS project focuses on a digital storytelling approach that can personalize the storytelling for the visitors, maximising the user-centred approach (Katifori et al., 2014) Proposing for the digitalisation of exhibits and presentations at the museum can give some financial solution for small to medium-sized museums. However, the economics of such project to be emulated by other museums world-wide may be of top concern. Regardless, it was mentioned that, there are feasible ways to design a digital storytelling presentation even with a small budget (Negrini \& Blas, 2014).

One of the economic methods that can be used in museum curations is by bringing the exhibits to life through effective use of communication tools. With story-driven exhibition designs, interaction with the objects would become more engaging. Importantly, Caulton (1998) had emphasized that there is a purpose for each display, a story to tell with each exhibit, an idea to unfold in each gallery. Objects tell stories about their owners, functions, and contexts, which allow visitors to make links to their purposes and memories. Depending on how the stories of the artefacts are told and perceived, various interpretations could emerge and give a different and new perspective of the artefacts 
INTERNATIONAL JOURNAL OF ACADEMIC RESEARCH IN BUSINESS AND SOCIAL SCIENCES Vol. 10, No. 9, 2020, E-ISSN: 2222-6990 @ 2020 HRMARS

(Dudley et al., 2012). More interestingly, visitor-generated stories in digital format could enrich the visiting experience and transform visitors into co-creators of meaning, extending the social role of the museum. However, the use of cutting-edge technology in museums has always been a financial concern to the stakeholders. It is worthy to highlight that collaborating in the creation of museum exhibitions can be an affordable solution for small and medium-sized museums (Valtolina, 2016).

\section{Information Visualisation for Museum Exhibition}

Card et al. (1999) define visualization as a computer-supported, interactive, visual representation of abstract data to amplify cognition. Through visual forms, users can understand data more easily and quickly than wading through a mass of numbers (Roberts et al., 2014). According to Benoit (2019), information visualization (InfoVis) is interactive, allowing viewers to converse with the data while gaining knowledge, exposing insights, and engaging with the data in unexpected ways. It is only through these conversations that the static display of data transforms into meaningful information. Essentially, visualization is useful to be part of explaining a problem, decision making, informed by the statistical underpinnings of the data, answer a question more deeply, and reduce the amount of displayed data into manageable chunks, but allowing details on demand. Different projects would use the visualization in multiple ways and for various reasons. Most visualization resources can be categorised in three categories; (i) stand-alone visualization applications, (ii) tools for creating interactive visualizations (usually web-based), and (iii) tools that visualize statistical data, either as a built-in part of the program or as a plug-in (Benoit, 2019) which is displayed in Figure 1.

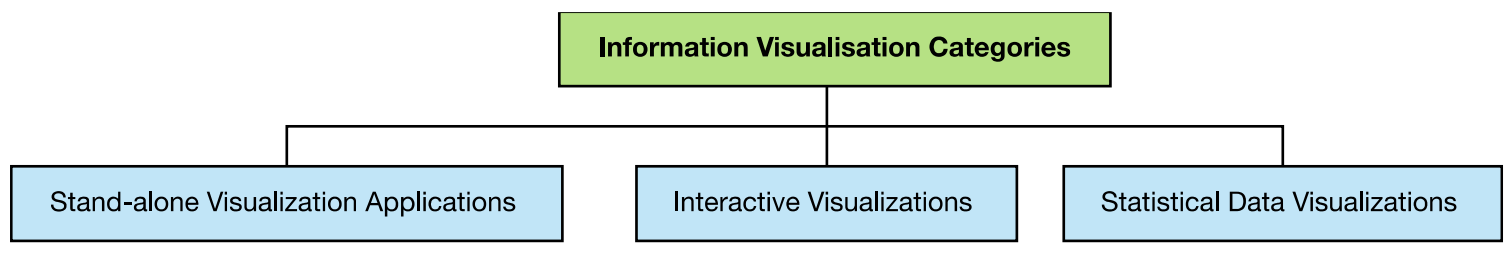

Figure 1: The categories of information visualisation (Benoit, 2019)

InfoVis exists in numerous ways in the everyday life. The first representation consists of written instructions on how to go from point A to point B using the digital Google maps. The second representation is an image of the route itself displayed on a map. Both of the representations represent value to different people. Both of these representations are examples of information visualization. The first relies on clear simple instructions with minimum graphical content conveying a simple set of useful instructions. The second conveys more data and in a visual form that allows for rapid cognitive processing and enabling users to quickly digest the information seen which is mentioned as the foundation of interaction design. There are common types of InfoVis as presentation to persuade or to understand a message or narrative such as the map of public train route and one of the famous ones of all is the London Underground. Also, InfoVis could be used as an approach to deliver analysis such as health situation rate or percentage to see the relationship of the data into visual. The type of InfoVis expands into the interaction and engaging style by putting in the emotion element with the storytelling approach of digital visualisation. Transforming data into a story is communicating data visually through info-graphics, video, animation, flowcharts, and written content to achieve effective communication. According to Seckin (2019), data storytelling is another 
INTERNATIONAL JOURNAL OF ACADEMIC RESEARCH IN BUSINESS AND SOCIAL SCIENCES Vol. 10, No. 9, 2020, E-ISSN: 2222-6990 @ 2020 HRMARS

method of collecting and presenting data through visualization that can be more intelligible in a narrative approach.

InfoVis enables data to be presented without any physical representation which is advantageous when museum artefacts cannot be physically displayed in public spaces. The traditional method of presenting data in text panels can now be visually displayed with interactive capabilities offering new potentials for museum exhibits (Hinrichs et. al., 2008). The use of information visualization approaches to digital cultural heritage collections reflect on prominent arrangement principles and design choices for digital collection interfaces and points out options for future research (Windhager et al., 2016). The first course in information visualisation would be an excellent introduction to many aesthetic, communicative, technical, and social aspects of data. Contemporary InfoVis is entering new terrain, uncharted, yet with many signposts. For example, engineers, computer scientists, and data mining experts have embraced some of the knowledge in graphic design practices while exploring and employing exceptional facility with the computer, data models, scripting, and programming. Collectively, the trend is to view InfoVis practice as an almost community-driven event. (Andrienko et al., 2016) made it clear that visualization is part of the public and business scene. The interpretation of information visualisation had change into a new perspective as it requires engaging with the image, breaking apart and viewing the composition, the data, and other visual messages on the page, not static images, icons, and charts (Benoit, 2019).

Economou and Meintani (2011) analysed sixty-four immersive and digital virtual museum applications in which fifty-four of the applications provided guided exhibition tours and general museum information. Many are audio guides with additional features such as an overall timetable or opening hours. Meanwhile, the other ten technologies focused on a single subject, the production or manipulation of content and games. Nevertheless, the content, delivery, and design of the applications facilitate specific applications before, during, and after the museum visit. They went on to explain how the applications address specific situations; for example, with location tracking, art labelling, museum photography, or social interaction. However, Economou and Meintani (2011) also informed that the applications presented do not discuss strategies apart from the direct representation of artworks due to the use of mobile applications. Hence, it would be useful to refer to Blumenstein et al. (2016) work that give a structured overview of the commonly used approaches for mobile visualization.

Isenberg, and Isenberg (2013) had collected papers from major visualisation conferences such as IEEE InfoVis, SciVis, EuroVis, and conferences for interactive display research such as ACM ITS and Smart Graphics. From a pool of over one thousand publications, the authors extracted 111 publications. The publications are then categorised by data, visual representation, types of display, input, research focus, and users. Seven mobile and twenty-six tablet visualizations we also presented; in comparison, ninety-eight of the visualizations use large shows like table-tops, drafting tables, or vertical displays. The publications were also categorised by research focus; $54 \%$ of the papers emphasized interaction, followed by the development of applications. Some of the topics which were addressed also revealed low percentage in collaboration, the development of software environments, and the technical setup. Good collections of mobile visualisations were also mentioned in a presentation at JSConf 2014 by Baur (2014); they are mobile visualisation (MobileVis, 2014) and mobileinfovis.com (Mobileinfovis, 
INTERNATIONAL JOURNAL OF ACADEMIC RESEARCH IN BUSINESS AND SOCIAL SCIENCES Vol. 10, No. 9, 2020, E-ISSN: 2222-6990 @ 2020 HRMARS

2015). Mobile Infovis structures the visualization by chart type and differentiates between smartphones and tablets. At MobileVis, the visualisations are not structured but presented by their added date. Meanwhile, Blumenstein, et. al (2017) presented fourty-two museum applications and installations and categorizes them in a matrix visualization. Blumenstein's (2017) research document also presented the museum names and location, the developers, functionality with bullet points, and images of the system. The matrix visualization presents the target audience, the devices, and the user experience through tags. It was also revealed that tablets and smartphones occurrences are the most used devices.

The user experience tags most common use would be for personalization, identifying a location, and gamification. On a more recent deployment, Windhager et. al. (2016) provided a structured overview of information visualization approaches for cultural heritage. The authors distinguished principles for visualizing cultural heritage in close up views, (multi) linear overviews, spatial encoding, and temporal encoding. They collected twenty-five information visualization approaches of cultural heritage collections and presented properties like used encoding, data focus, and type of project in a table. Unfortunately, information about the targeted device types was absent from the report. However, Langner et. al. (2015) had further described three promising aspects of InfoVis on mobile devices. Those aspects are the development of a consistent multi-touch interaction framework that can be applied to a variety of visualization techniques; the combination of common touch input with advanced spatial input techniques; and the usage of the spatial arrangement of multiple, co-located mobile devices.

They also mentioned the advantages of using mobile devices which include the devices' ubiquity and usability that can be exploited almost anywhere and at any time. The authors noted that the broad success and the availability in the consumer market make these devices the ideal platform for bringing InfoVis to even inexperienced users. Roberts et al. (2014) put forth a good definition of what visualisation is and what opportunities it holds for the future. It was mentioned that only a few papers from the Institute of Electrical and Electronics Engineers (IEEE) Information Visualization Conference use computer hardware other than desktop or laptop computers. The increasing variety of computer hardware from small hand-held smartphones to immersive multi-wall display systems brings new possible applications even to casual users. The user's context is getting more critical especially for mobile technology and the ability for smartphones to have many usages aside from the desktop computers. Therefore, the smartphone has to adapt to the users' current context as supported with critical human-computer interaction paradigms because the future of visualizations is becoming a fluid interaction (Roberts et. al., 2014). The convergence of input and output technology in the environment, integrated sensory interaction such as head-mounted displays to create virtual reality and mixed reality where computer-generated and physical objects coexist is inevitable with more technological innovation ahead of social movement.

\section{Affective Factors in the Museum through DST and InfoVis}

Designing an effective exhibition can be judged in two ways visitor measures or critical appraisal by experts. Visitor measures include behaviour, knowledge, and affect. The crucial assessment by experts can take the views of a visitor studies expert, the subject matter and the artist. There are two sections of successful criteria the visitor measures are of three types: behavioural, knowledge 
INTERNATIONAL JOURNAL OF ACADEMIC RESEARCH IN BUSINESS AND SOCIAL SCIENCES Vol. 10, No. 9, 2020, E-ISSN: 2222-6990 @ 2020 HRMARS

acquisition and affective and approaches to exhibit designs with three basic approaches 1) subject matter, 2) aesthetic, and 3) hedonistic. Many of the problems in an exhibition design team can be traced to gaps in the fundamental design philosophy. Such practitioners (often specialists in the specific discipline) attempt to saturate the show with accurate information, regardless of the audience's cognitive processing capacity. Here, this approach is called the "subject-matter" method. Other professionals (often with training in art and design) may be primarily concerned with adherence to traditional principles of art. Such individuals emphasize the "aesthetic" approach. Still, other professionals (often advocates of let kids play as an end in itself) are concerned primarily with designs that produce fun experiences with less concern for educational or aesthetic goals and consider the "hedonistic" approach. In contrast, all three approaches have benefits and should be considered. The overemphasizing one and neglecting the other criteria is likely to create problems with exhibit effectiveness due to failure to communicate important messages, failure to be attractive or failure to create a satisfying visitor experience (Bitgood, 1994).

Through selected literature review in museum exhibition design, show finding on affective of the visitors that enhance the user experiences. All the study shown implemented of new collaboration tools, approach and techniques into the museum exhibition and presentation for the enhancement of cultural and heritage field. Table 2 shown result of affective on museum design. The affective results focus on engagement, emotional and empathy that mostly on visitor or user experience. This guide this study to understand the National Museum Department (Jabatan Muzium Negara) (JMN) within the Klang Valley on DST and InfoVis museum exhibition application to enhance the museum content presentation.

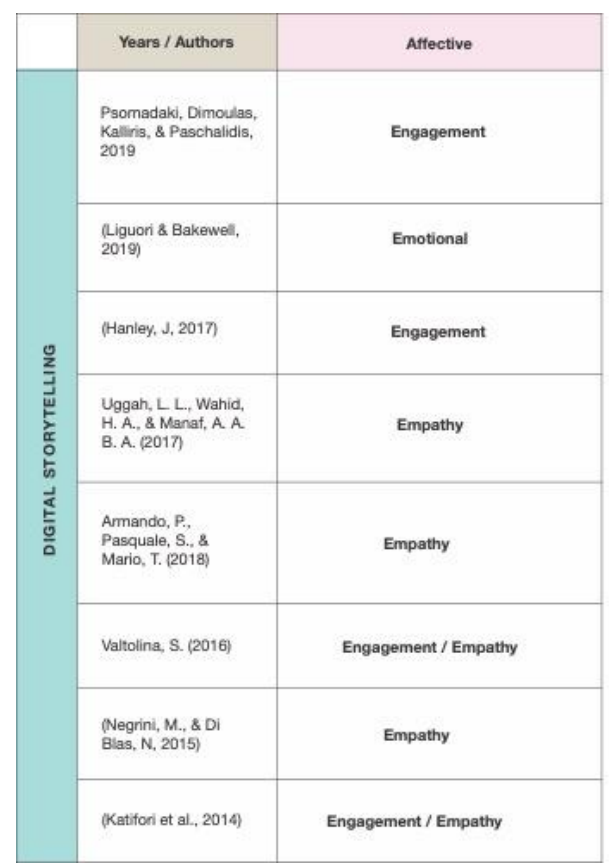

\begin{tabular}{|c|c|c|}
\hline & Years / Authors & Affective \\
\hline \multirow{9}{*}{ 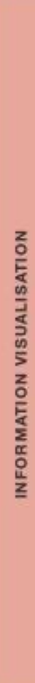 } & $\begin{array}{l}\text { Hammady, R., Ma, M., \& } \\
\text { Stratheam, C. (2019) }\end{array}$ & Engagement \\
\hline & $\begin{array}{l}\text { Carvalho, P., Parisot, O., \& } \\
\text { Tamisler, T. (2017, July) }\end{array}$ & Empathy \\
\hline & $\begin{array}{l}\text { Isenberg, P. \& Isenberg, } \\
\text { T. (2013). }\end{array}$ & Engagement \\
\hline & $\begin{array}{l}\text { Blumenstein, K. (2018, } \\
\text { November) }\end{array}$ & Empathy \\
\hline & $\begin{array}{l}\text { Langner, R., Horak, T. \& } \\
\text { Dachselt, R. (2015) }\end{array}$ & Empathy \\
\hline & Roberts, J. et al., (2014) & Empathy \\
\hline & Benoit, G. (2019) & Engagement / Empathy \\
\hline & Windheger, F. et al., 2016) & Empathy \\
\hline & $\begin{array}{l}\text { Economou, M. \& \& } \\
\text { Meintani, E. (2011) }\end{array}$ & Empathy \\
\hline
\end{tabular}

Table 2 Synthesizing literature review on affective factors in DST and InfoVis implementation in a museum. 
INTERNATIONAL JOURNAL OF ACADEMIC RESEARCH IN BUSINESS AND SOCIAL SCIENCES Vol. 10, No. 9, 2020, E-ISSN: 2222-6990 @ 2020 HRMARS

The User Interface Design (UID) process has skewed towards human-centered design. According to (Saffer, 2009), all these disciplines fall under one "big" umbrella known as User Experience (UX). It is one of the most important principles used when designing, describing, or improving how users feel when interfacing with a system. The system may be defined as computer applications, software, or web pages. Designing a museum information visualisation (InfoVis) need to take the important point of user needs. The user experience design process is all about ensuring that no aspect of the user's experience with your product happens without your conscious. All aspects must be taken into consideration in every possible action that the user needs and consider the user's expectations at every point.

In designing a product requirement specification: need at the beginning of the project to describe what the system should do and functionality specification: on the functionality side, we're concerned with what would be considered the feature set of the application. In addition, content specification is part of the process, but photos, audio, and video may be more critical than accompanying text. All the stages lead to create an engaging, efficient user experience known as user-centered design (Garrett, 2010).

The conceptual framework in Figure 2 shows the functional specifications new elements of user experience (UX) that create engaging, efficient or known as user-centered design. In this study, the functional specification will be taking place as to identify the digital storytelling (DST) elements and information visualisation (InfoVis) types in museum and analyse as to conclude the content requirement to propose a practical framework to the route of user experience enhancement. User experience enhancement will be based on the affectiveness; visitors reaction and the gatekeeper curator and designer team for feedback.

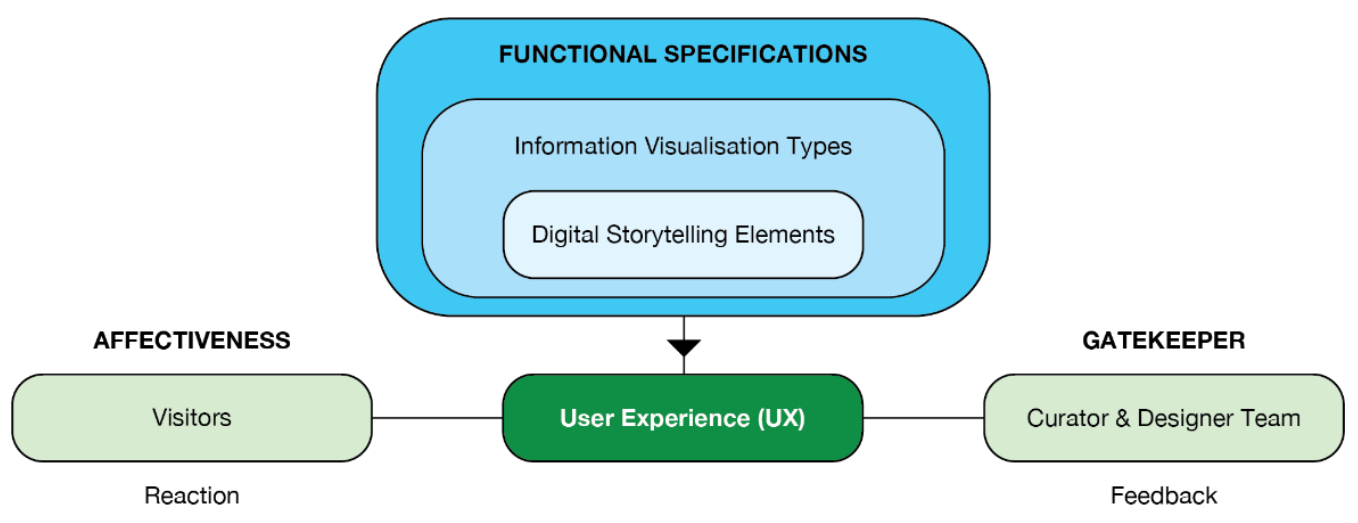

Figure 2: Functional Specifications for User Experience (UX) Enhancement for Museum Exhibition

\section{Methodology}

Design

The use of systematic literature review (SLR) in this paper is a way of reviewing and analysing all available research related to a specific research issue, subject area or phenomenon of interest. Systematic reviews seek to provide a fair assessment of a research subject using a credible, comprehensive and auditable methodology. The aim of a systematic review is to create a general 
INTERNATIONAL JOURNAL OF ACADEMIC RESEARCH IN BUSINESS AND SOCIAL SCIENCES Vol. 10, No. 9, 2020, E-ISSN: 2222-6990 @ 2020 HRMARS

vision of a particular issue and give it a fair description of literature (Nightingale, 2009). The rationale for this approach in this analysis is to summarise current literature on museum technology and approach. Besides, summarising the empirical evidence of the advantages and disadvantages of a particular agile process, identifying any gaps in current research to suggest areas for further study and presenting a context or background to properly place new research objectives. This study aims to define the variables of implementing DST on InfoVis in museum exhibition through previous studies. Total 17 literature reviews based primarily data on DST and InfoVis regarding museum exhibits described the museum visitor's affectivity and the differences in previous studies.

\section{Conclusion}

This paper is intended to look into the understanding and identifying the key elements of content requirement for museum exhibitions through digital storytelling (DST). It also seeks for the elements necessary for designing effectual DST on information visualisation (InfoVis) types through the literature review for user experience enhancement. The development of DST internationally for museum exhibitions had extended to another level with the combination of other tools and application such as information visualisation (InfoVis). However, there is a gap of literature with regard to implementing the elements of DST on museum exhibitions in Malaysia context. Additionally, Malaysian scholars mostly reported on the approaches and techniques used in Malaysian towards museum enhancement and exhibition presentations for visitor experiences. However, they have suggested and hoped to implement the use of current digital technologies such as digital media, VR, AR, and interactive storytelling for Malaysian museums. To date no study explicitly reports on the elements used in museum exhibitions' content with regard to product's narration. Furthermore, the information visualization (InfoVis) available in the National Museum Department (JMN) museums only projected documentary videos, dioramas, artefacts with narration but without the specific elements of digital storytelling such as the short, first-person video narrative created by combining recorded voice, still images and music or other sounds (Mullen, 1994). Digital storytelling (DST) is implemented only through the surface, not the content. These are the elements that are lacking that make the information visualization (InfoVis) style and content of JMN's museums are not meaningful, less engaging, or less interactive. Further research is required to understand the museum exhibition content requirement as enhancement can be done for future generations to enjoy, engage and interact with historical stories.

\section{References}

Andrienko, G., Andrienko, N., Dykes, J., Kraak, M. J., Robinson, A; Schumann, H. (2016). GeoVisual analytics: interactivity, dynamics, and scale. Cartography and Geographic Information Science, 43(1), 1-2. https://doi.org/10.1080/15230406.2016.1095006

Allen, K., Hollinworth, N., Hwang, F., Minnion, A., Kwiatkowska, G., Lowe, T., \& Weldin, N. (2013). Interactive sensory objects for improving access to heritage. In CHI'13 Extended Abstracts on Human Factors in Computing Systems. 2899-2902.

Banaszewski, T. M. (2005). Digital storytelling: Supporting digital literacy in grades 4-2. Master of Science in Information Design and Technology Thesis, Georgia Institute of Technology, Atlanta, Georgia.

Benoit, G. (2019). Introduction to information visualization: Transforming data into meaningful information. Rowman \& Littlefield. 
INTERNATIONAL JOURNAL OF ACADEMIC RESEARCH IN BUSINESS AND SOCIAL SCIENCES Vol. 10, No. 9, 2020, E-ISSN: 2222-6990 @ 2020 HRMARS

Bitgood, S. (1994). Designing effective exhibits: Criteria for success, exhibit design approaches, and research strategies. Visitor Behavior, 9(4), 4-15.

Blumenstein, K. (2018). Interweaving Physical Artifacts with Visualization on Digital Media in Museums. In Proceedings of the 2018 ACM Companion International Conference on Interactive Surfaces and Spaces. 1-6.

Caulton, T. (1998). Hands-on exhibitions: Managing interactive museums and science centres. Oxon: Routledge.

Card, S. K., Mackinlay, J.D. \& Shneiderman, B. (1999). Readings in information visualization: using vision to think. Morgan Kaufmann.

Davis, S. B., Vane, O., \& Kräutli, F. (2016). Using Data Visualisation to tell Stories about Collections. https://doi.org/10.14236/ewic/eva2016.44

Dudley, S., Barnes, A., Binnie, J., Petrov, J., and Walklate, J., 2012. Narrating objects, collecting stories. Oxon: Routledge.

Economou, M. \& Meintani, E. (2011). Promising Beginning? Evaluating Museum Mobile Phone Apps. University of Limerick, Ireland. Retrieved at 2018-02-25 from http://www.idc.ul.ie/techmuseums11/

Garrett, J. J. (2010). The Elements of User Experience. Pearson Education (US).

Gubrium, A. C., Krause, E. L., \& Jernigan, K. (2014). Strategic Authenticity and Voice: New Ways of Seeing and Being Seen as Young Mothers Through Digital Storytelling. Sexuality Research and Social Policy, 11(4), 337-347. doi: 10.1007/s13178-014-0161-x

Gubrium, A. (2009). Digital Storytelling: An Emergent Method for Health Promotion Research and Practice. Health Promotion Practice, 10(2), 186-191. doi: 10.1177/1524839909332600

Bin Harun, H., Sintok, K., \& Shiratuddin, N. (2009). Preference of Expert Proposed Digital Storytelling Elements: Students' Perspectives.

Hinrichs, U., Schmidt, H., \& Carpendale, S. (2008). EMDialog: Bringing information visualization into the museum. IEEE transactions on visualization and computer graphics, 14(6), 1181-1188.

Hornecker, E., \& Stifter, M. (2006, November). Learning from interactive museum installations about interaction

design for public settings. In Proceedings of the 18th Australia conference on Computer-Human Interaction: Design: Activities, Artefacts and Environments (pp. 135-142).

Isenberg, P., \& Isenberg, T. (2013). Visualization on Interactive Surfaces: A Research Overview / Visualisierung auf interaktiven Oberflächen: Ein Forschungsüberblick. I-Com, 12(3). https://doi.org/10.1515/icom.2013.0020

Lambert, J. (2006). Digital storytelling: Capturing lives, creating community (2nd ed.). Berkelay, CA: Digital Diner Press.

Kamaruddin, N. (2019). An Empirical Understanding On Types Of Museum Exhibition Design. International Journal of Scientific and Research Publications (IJSRP), 9(10). https://doi.org/10.29322/ijsrp.9.10.2019.p9470

Katifori, A., Karvounis, M., Kourtis, V., Kyriakidi, M., Roussou, M., Tsangaris, M., Pujol, L. (2014). CHESS: Personalized Storytelling Experiences in Museums. Interactive Storytelling Lecture Notes in Computer Science, 232-235. doi:10.1007/978-3-319-12337-0_28

Langner, R., Horak, T., \& Dachselt, R. (2015). Information Visualizations with Mobile Devices: Three Promising Aspects. In Workshop on Data Exploration for Interactive Surfaces DEXIS 2015 (S. 20). Retrieved from https://petra.isenberg.cc/ 
INTERNATIONAL JOURNAL OF ACADEMIC RESEARCH IN BUSINESS AND SOCIAL SCIENCES

Vol. 10, No. 9, 2020, E-ISSN: 2222-6990 @ 2020 HRMARS

publications/papers/Isenberg_2015_PWD.pdf\#page=22

Nee, T. Y., Mohammed, N. B., \& UTEM, M. (2014) Implementation of 3D Augmented Reality in Mobile Application to Nurture Children Knowledge for Museum Artifact.

Negrini, M., \& Blas, N. D. (2014). Digital Storytelling for Cultural Heritage: A Modular, Multi-channel, Multi-scenario Approach. Built Heritage: Monitoring Conservation Management Research for Development, 367-375. doi:10.1007/978-3-319-08533-3_31

Journal of Scientific and Research Publications (IJSRP) 9(10) (ISSN: 2250-3153), DOI: http://dx.doi.org/10.29322/IJSRP.9.10.2019.p9470

Ohler, J. (2008). Digital storytelling in the classroom: New media pathways to literacy, learning, and creativity. Thousand Oaks, CA: Corwin Press.

Porter, B. (2004). Digitales: The art of telling digital stories. Sedalia, CO: bjpconsulting.

Robin, B. (2006). The Educational Uses of Digital Storytelling. Paper presented at the Society for Information

Technology \& Teacher Education International Conference 2006, Orlando, Florida, USA.

Roberts, J. C., Ritsos, P. D., Badam, S. K., Brodbeck, D., Kennedy, J., \& Elmqvist, N. (2014). Visualization beyond the Desktop the Next Big Thing. IEEE Computer Graphic and Applications, 34 (6), 2634. doi 10.1109/MCG.2014.82

Rosli, H., \& Kamaruddin, N. (2020). Visitor Experience's on Digital Media Technology for the Museum Exhibition in Malaysia: A Preliminary Findings. Retrieved August 13, 2020, from https://www.rsisinternational.org/virtual-library/papers/visitor-experiences-on-digitalmedia-technology-for-the-museum-exhibition-in-malaysia-a-preliminary-findings/

Saffer, D. (2009). Designing for interaction: Design research.

Seçkin, E. (2019). Data Storytelling: Verinin Hikâyeleştirilmesi. Retrieved from http://creathinks.com/icerik-yonetimi-tr/data-storytelling-verinin-hikayelestirilmesi/

Schafer, L. (2008). Investigations on digital storytelling: The development of a reference model. Saarbrucken, Germany: VDM Verlag.

Tenh, H. K., Shiratuddin, N., \& Harun, H. (2012). Core elements of digital storytelling from experts' perspective.

Weber, W., \& Tille, R. (2011). Listening to Managers: A Study about Visualizations in Corporate Presentations. 2011 15th International Conference on Information Visualisation. https://doi.org/10.1109/iv.2011.28

Windhager, F., Federico, P., Mayr, E., Schreder, G., \& Smuc, M. (2016). A Review of Information Visualization Approaches and Interfaces to Digital Cultural Heritage Collections. In FMT (pp. 74-81).

Valtolina, S. (2016). A Storytelling-Driven Framework for Cultural Heritage Dissemination. Data Science and Engineering, 1(2), 114-123. https://doi.org/10.1007/s41019-016-0007-z

Vecchi, N. D., Kenny, A., Dickson-Swift, V., \& Kidd, S. (2016). How digital storytelling is used in mental health: A scoping review. International Journal of Mental Health Nursing, 25(3), 183-193. doi: 10.1111/inm.12206 